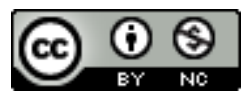

Jurnal Pendidikan Matematika Indonesia is licensed under A Creative Commons Attribution-Non Commercial 4.0 International License.

\title{
MODEL PEMBELAJARAN KOOPERATIF TIPE NUMBERED HEAD TOGHETHER (NHT) TERHADAP KEMAMPUAN PENALARAN MATEMATIKA SISWA
}

\author{
Silfanus Jelatu ${ }^{1)}$, Maria Irmayati Amul ${ }^{2)}$, Eufrasia Jeramat ${ }^{3)}$, Ricardus Jundu ${ }^{4)}$ \\ 1) STKIP Santu Paulus, Ruteng, Indonesia \\ E-mail: silfanusjelatu@yahoo.co.id \\ ${ }^{2}$ STKIP Santu Paulus, Ruteng, Indonesia \\ E-mail:Iraamul24@gmail.com \\ ${ }^{3}$ STKIP Santu Paulus, Ruteng, Indonesia \\ E-mail: Eva.jeramat@gmail.com \\ ${ }^{4)}$ STKIP Santu Paulus, Ruteng, Indonesia \\ E-mail: rickyjundu@gmail.com
}

\begin{abstract}
Abstrak.Penelitian ini bertujuan untuk mengetahui apakah kemampuan penalaran matematis siswa yang diajarkan dengan menggunakan model Pembelajaran kooperatif tipe Numbered Head Together (NHT) lebih baik dibandingkan dengan kemampuan penalaran matematis siswa yang diajarkan dengan menggunakan pembelajaran konvensional pada siswa kelas XI SMAK St. Thomas Aquinas Ruteng tahun ajaran 2018/2019. Penelitian ini merupakan penelitian eksperimen dengan quasi-experimental design. Populasi dalam penelitian ini adalah seluruh siswa kelas XI Bahasa SMAK St. Thomas Aquinas Ruteng tahun ajaran 2018/2019 yang terdiri atas dua kelas dengan jumlah 64 siswa. Pengambilan sampel dilakukan dengan random kelas. Jumlah sampel penelitian adalah 64 orang. Data kemampuan penalaran matematis dikumpulkan dengan tes uraian. Data dianalisis dengan menggunakan uji $t$. Berdasarkan hasil analisis data diperoleh bahwa hasil perhitungan $t_{\text {hitung }}=6,003$ dan $t_{\text {tabel }}=1,999$ pada taraf signifikan 5\% dengan $d k=62$. karena $t_{\text {hitung }}>t_{\text {tabel }}$ maka $H_{0}$ ditolak dan $H_{1}$ diterima, yang artinya kemampuan penalaran matematis siswa yang diajarkan dengan model pembelajaran kooperatif tipe Numbered Head Together (NHT) lebih baik dibandingkan dengan kemampuan penalaran matematis siswa yang diajarkan dengan pembelajaran konvensional.
\end{abstract}

Kata Kunci: Pembelajaran Kooperatif, NHT, Kemampuan Penalaran Matematis

\section{PENDAhUluan}

Dalam abad ke-21 ini, seluruh kehidupan manusia sudah mempergunakan matematika. Demikian pula ilmu-ilmu pengetahuan semuanya sudah mempergunakan matematika. Young, Edwards, \& Leising (2010) menegaskan kembali pernyataan Thurston yang menggambarkan matematika melalui metafora "Mathematics isn't a palm tree, but mathematics is a banyan tree". Jadi, sangatlah tidak tepat apabila matematika dipandang hanya ada dalam dunia matematika. Matematika berperanan penting dalam mengembangkan berbagai disiplin ilmu serta mengembangkan daya pikir manusia, sehingga matematika menjadi fondasi dalam perkembangan imu pengetahuan dan teknologi (Kurniati, Prahmana, Makur, \& Jelatu, 2018).

Kurnila (2013) menerangkan bahwa agar dapat memasuki dan menguasai dunia ilmu pengetahuan, maka harus memahami dan mempelajari matematika, sekurang- kurangnya pada tingkat dasar dan menengah. Dengan belajar matematika di sekolah, siswa dilatih untuk berpikir kreatif, kritis, analitis, serta dapat mengaplikasikan ilmu matematika dalam menyelesaikan suatu permasalahan sehari-hari maupun dalam disiplin ilmu lainnya. Pembelajaran matematika di sekolah diharapkan mampu menggali potensi siswa agar dapat memahami matematika dengan benar (Jelatu, Sariyasa, \& Ardana, 2018).

Pembelajaran matematika di sekolah bukan hanya mengarahkan siswa menghafal konsep, tetapi harus mampu memahami konsep tersebut serta mampu menerapkan konsep-konsep tersebut dalam kehidupan sehari-hari (Ali, Murni, \& Jelatu, 2018; Bardini, Pierce, Vincent, \& King, 2014). Tujuan umum mempelajari matematika ialah membuat seseorang memperoleh pengetahuan matematika yang dibutuhkan setiap hari, mengajarkan bagaimana memecahkan masalah, membuatnya memiliki metode 


\section{- - - Jurnal Pendidikan Matematika Indonesia \\ Volum 4 Nomor 1 bulan Maret 2019 Page 12 - 17 \\ p-ISSN: 2477-5967 e-ISSN: 2477-8443}

memecahkan masalah dan memperoleh metode penalaran (Altun \& Memnun, 2008)

Kemampuan penalaran merupakan salah satu kemampuan dasar yang harus dikuasai siswa dalam mempelajari ilmu apa saja. Dalam kaitannya dengan dunia matematika, penalaran matematis merupakan salah satu kemampuan yang harus dimiliki siswa untuk memahami matematika (Lehrer \& Schauble, 2000). Di dalam Kurikulum Tingkat Satuan Pendidikan (Depdiknas, 2006) dirumuskan bahwa salah satu tujuan dari pembelajaran matematika di sekolah baik dasar maupun menengah adalah agar siswa mampu menggunakan penalaran pada pola dan sifat, melakukan manipulasi matematika dalam membuat generalisasi, menyusun bukti, atau menjelaskan gagasan dan pernyataan matematika.

Unal (2005) mengartikan penalaran sebagai suatu proses mencapai pemikiran rasional dengan mempertimbangkan semua faktor. Selanjutnya, Mueller, Yankelewitz, \& Maher (2014) menegaskan bahwa penalaran adalah proses berpikir yang berusaha menghubungkan fakta-fakta atau evidensievidensi yang diketahui menuju kepada suatu kesimpulan.

Penalaran dibedakan menjadi dua yaitu penalaran induktif dan penalaran deduktif (Hendriana \& Sumarmo, 2014). Selanjutnya (Hendriana \& Sumarmo, 2014), menyatakan bahwa penalaran induktif merupakan cara berpikir dimana suatu kesimpulan yang bersifat umum ditarik dari berbagai kasus yang bersifat individual. Sedangkan penalaran deduktif merupakan cara berpikir dimana dari pernyataan umum ditarik kesimpulan yang bersifat khusus. Melalui penalaran matematika siswa dapat mengajukan dugaan kemudian menyusun bukti, melakukan manipulasi terhadap soal, dan menarik kesimpulan dengan benar dan tepat. Dengan memiliki kemampuan bernalar yang baik, siswa akan mampu memecahkan masalah dan mampu mengambil kesimpulan dalam permasalahan sehari-hari.

Faradillah (2018) memandang matematika sebagai cara bernalar, karena matematika memuat cara pembuktian yang valid, serta sifat penalaran matematika yang sistematis. Penalaran matematis merupakan suatu kebiasaan otak yang apabila dikembangkan dengan baik dan konsisten akan memudahkan dalam mengomunikasikan matematis baik secara tertulis maupun lisan (Ainun, 2015). Riyanto \& Siroj (2011) menerangkan kembali pernyataan Ball, Lewis \& Thamel bahwa penalaran matematika adalah fondasi untuk mendapatkan atau menkonstruk pengetahuan matematika. Di sisi lain Ratnasari \& Abadi (2018) menghubungkan keterampilan penalaran matematika sebagai salah satu keterampilan standar matematika yang harus dikuasai dalam literasi matematika. Penalaran matematis adalah keterampilan peserta didik untuk memberikan alasan dan membuktikan hasil pemikiran mereka menggunakan waktu dan cara atau prosedur yang tepat.

Salah satu fakta yang ditemukan peneliti khususnya terkait kemampuan penalaran matematika siswa di SMA Swasta St. Thomas Aquinas Ruteng, NTT adalah rendahnya kemampuan penalaran matematika. Hal ini namapk dalam kesulitankesulitann seperti siswa masih kesulitan dalam mengajukan dugaan yakni menemukan cara atau langkah-langkah penyelesaian yang tepat untuk menyelesaikan permasalahan matematika, siswa belum dapat melakukan manipulasi matematika, serta kemampuan siswa dalam menarik kesimpulan juga masih sangat kurang.

Salah satu faktor yang diyakini dapat meminimalisasi persoalan di atas adalah melalui perubahan model pembelajaran yang dilakukan di kelas. Model pembelajaran sangat berpengaruh dalam upaya meningkatkan prestasi matematika belajar. Penggunaan model pembelajaran yang tepat dapat mendorong rasa bahagia siswa terhadap pelajaran dan mampu mencapai hasil pembelajaran yang lebih baik (Irawan, Mardiyana, \& Sari Saputro, 2017). Wahyuni (2018) merekomendasikan pembelajaran yang kreatif dan dinamis serta mengakomodasi beragam karakteristik siswa. Model pembelajaran yang kreatif dan dinamis serta tepat untuk membuat siswa lebih aktif adalah kooperatif. Salah satu model pembelajaran kooperatif yang dapat digunakan adalah model pembelajaran kooperatif tipe Numbered Head Together (NHT).

Model pembelajaran kooperatif tipe Numbered Head Together (NHT) merupakan salah satu dari model pembelajaran kooperatif yang dikembangkan oleh Speser Kagan (Lince, 2016). Dalam Model pembelajaran kooperatif tipe Numbered Head Together (NHT), siswa belajar bersama dalam kelompoknya masing-masing. Setiap anggota kelompok akan mendapat tugas dengan nomor yang berbedabeda. Hal ini berarti setiap siswa mendapatkan kesempatan yang sama untuk menunjang timnya guna memperoleh nilai yang maksimal sehingga termotivasi untuk belajar. Dengan demikian, siswa merasa mendapat tugas dan tanggung jawab. Tugas dan tanggung jawab itulah yang akan memotivasi siswa untuk belajar dan berusaha sehingga tujuan pembelajaran dapat tercapai secara optimal.

Model pembelajaran kooperatif tipe NHT membantu siswa untuk mengembangkan pemahaman mereka ketika melakukan interaksi sosial dalam kelompok dan saat presentasi. NHT menekankan tanggung jawab anggota untuk melakukan tugas mereka berdasarkan jumlah (Leasa \& Corebima, 2017). Siswa dapat menunjukkan kemampuan mereka dan menggunakan strategi apa pun untuk menyelesaikan tanggung jawab mereka. Siswa juga dilatih untuk memahami setiap tugas secara komprehensif (Sugihatno, Budiyono, \& Slamet, 2017). Oleh karena itu, tanggung jawab siswa tidak hanya pada proyek individu, tetapi juga sebagai anggota kelompok tertentu. Dengan demikian, NHT dapat meningkatkan pencapaian kognitif siswa. Selain itu, sebagai bagian dari pembelajaran model kooperatif, NHT memberikan kontribusi peningkatan keterampilan sosial siswa, ketika mereka berinteraksi dengan guru dan rekan-rekan selama pembelajaran (Indarti, Mardiyana, \& Pramudya, 2017).

Menurut Kusuma \& Maskuroh (2017), model pembelajaran kooperatif tipe Numbered Head Together (NHT) merupakan suatu model pembelajaran berkelompok yang setiap anggota kelompoknya bertanggung jawab atas tugas kelompoknya, sehingga tidak ada pemisahan antara siswa yang satu dengan siswa yang lain dalam satu kelompok untuk saling memberi dan menerima antara satu dengan yang lainnya. Model pembelajaran kooperatif NHT merupakan 
sebuah variasi diskusi kelompok yang ciri khasnya adalah guru hanya menunjuk seorang siswa yang mewakili kelompoknya tanpa memberitahu terlebih dahulu siapa yang akan mewakili kelompoknya (Indarti, Mardiyana, \& Pramudya, 2017). Model pembelajaran kooperatif pendekatan struktural Numbered Heads Together dirancang untuk mempengaruhi pola interaksi siswa dan memiliki tujuan untuk meningkatkan penguasaan akademik setiap siswa. Dengan belajar secara kooperatif, siswa akan saling berinteraksi dalam mencari dan menemukan jawaban kelompok yang benar.

Beberapa penelitian telah membuktikan bahwa model pembelajaran kooperatif tipe Numbered Head Togethet (NHT) efektif untuk pembelajaran matematika (Khoirotunnisa, 2015; Lince, 2016; Rahmawati, 2017; Sutriningsih, Pratiwi, \& Utami, 2018). Hasil penelitian mereka menunjukkan bahwa penggunaan model pembelajaran kooperatif tipe Numbered Head Together (NHT) Together (NHT) dapat meningkatkan prestasi belajar matematika siswa serta kemampuan berpikir kreatif siswa dalam pembelajaran matematika.

Melalui penerapan model pembelajaran yang berbeda tentu akan memberikan hasil yang berbeda pula. Oleh karena itu, peneliti tertarik untuk meneliti lebih lanjut terkait perbandingan kemampuan penalaran matematis siswa yang diajarkan dengan menggunakan model pembelajaran kooperatif tipe Numbered Head Together (NHT) dan kemampuan penalaran matematis siswa yang diajarkan dengan menggunakan pembelajaran konvensional. Adapun tujuan dari penelitian ini adalah untuk mengetahui apakah kemampuan penalaran matematis siswa yang diajarkan dengan menggunakan model pembelajaran kooperatf tipe Numbered Head Together (NHT) lebih baik dibandingkan dengan kemampuan penalaran matematis siswa yang diajarkan dengan pembelajaran konvensional pada siswa kelas XI SMAK St. Thomas Aquinas Ruteng?

\section{Metode Penelitian}

Penelitian ini merupakan penelitian eksperimen semu dengan desain penelitian Posttest only control group design. Penelitian ini dilakukan di SMAK St. Thomas Aquinas Ruteng. Populasi dalam penelitian ini adalah seluruh siswa kelas XI Bahasa SMAK St. Thomas Aquinas Ruteng tahun ajaran 2018/2019 yang tersebar dalam 2 kelas dengan jumlah 64 siswa.Untuk keperluan penelitian kedua kelas dipilih dua secara acak utuk dijadikan kelas eksperimen dan kelas kontrol, yang terlebih dahulu diuji kesetaraannya dengan uji t. Kelas-kelas tersebut dapat dijadikan sebagai kelas penelitian apabila memiliki kemampuan yang setara, dan dikatakan setara jika $t_{\text {hitung }}<t_{\text {tabel }}$. Berdasarkan hasil uji kesetaraan, diperoleh bahwa kedua kelas setara sehingga kedua kelas tersebut dapat dijadikan sebagai kelas penelitian.

Data yang dikumpulkan dalam penelitian ini adalah data kemampuan penalaran matematika siswa. Instrumen yang digunakan untuk pengumpulan data adalah tes kemampuan penalaran matematis siswa. Tes dilaksanakan setelah proses pembelajaran. Soal test terdiri dari 5 nomor soal uraian yang disusun berdasarkan indikator kemampuan penalaran matematis siswa.

Sebelum digunakan, instrumen tersebut diuji validitas dan reliabilitasnya. Pengujian validitas instrumen menggunakan rumus korelasi product moment. Instrument dikatakan valid apabila $r_{\text {hitung }} \geq r_{\text {tabel }}$ pada taraf signifikan 5\%. Ringkasan hasil uji validitas instrumen kemampuan penalaran matematis siswadapat dilihat pada Tabel I.

TABEL I

HASIL UJI VALIDITAS INSTRUMEN

\begin{tabular}{cccc}
\hline No. soal & $\mathbf{r}_{\text {hitung }}$ & $\mathbf{r}_{\text {tabel }}$ & Keterangan \\
\hline 1 & 0,578 & 0,388 & Valid \\
2 & 0,501 & 0,388 & Valid \\
3 & 0,571 & 0,388 & Valid \\
4 & 0,543 & 0,388 & Valid \\
5 & 0,575 & 0,388 & Valid \\
6 & 0,319 & 0,388 & Tidak Valid \\
7 & 0,106 & 0,388 & Tidak Valid \\
\hline
\end{tabular}

Pengujian reliabilitas instrumen menggunakan rumus alpha Cronbach. Hasil uji reliabilitas tes kemampuan penalaran matematis siswa diperoleh nilai reliabilitas sebesar 0,62 sehingga tes ini dikategorikan memiliki nilai reliabilitas tinggi. Selanjutnya dilakukan uji hipotesis menggunakan uji t untuk mengetahui apakah kemampuan penalaran matematis siswa yang diajarkan dengan menggunakan model pembelajaran kooperatif tipe Numbered Head Together (NHT) lebih baik dibandingkan dengan kemampuan penalaran matematis siswa yang diajarkan dengan menggunakan pembelajaran konvensional.

\section{HASIL DAN PEMBAHASAN}

Statistik deskriptif data yang dihitung diantaranya data posttest dari kelas eksperimen dan data posttest dari kelas kontrol.Statistik deskriptif data posttest dari kelas eksperimen dapat dilihat pada Gambar 1.

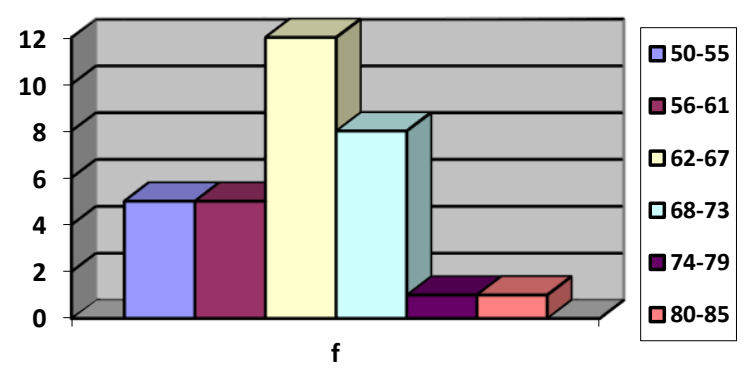

Gambar 1 Histogram Statistik Deskriptif data posttest kelas eksperimen

Berdasarkan hasil statistik deskriptif data posttest yang disajikan pada Gambar 1 di atas, dapat diketahui bahwa pada kelas eksperimen nilai maksimum 83, nilai minimum 50, rata-rata 64,13, varians 51,75, dan standar deviasi yaitu 8,01. 
Statistik deskriptif data posttest dari kelas control dapat dilihat pada Gambar 2.

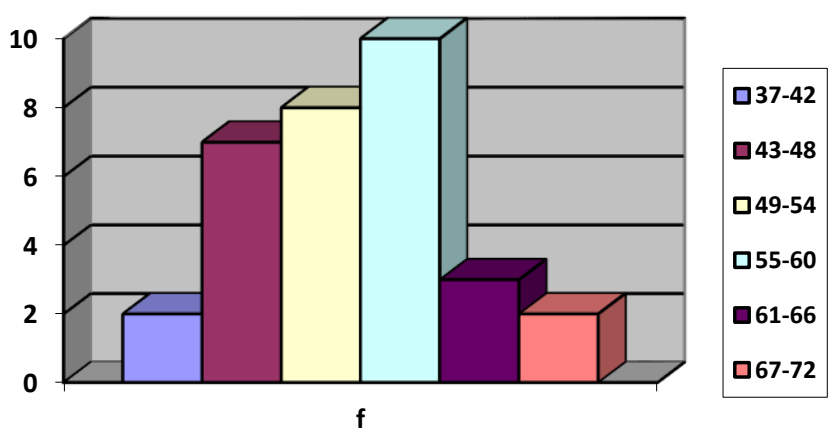

Gambar 2. Histogram Statistik Deskriptif data posttest kelas kontrol

Berdasarkan histogram pada Gambar 2 di atas, dapat diterangkan bahwa pada kelas kontrol diperoleh nilai maksimum 70 , nilai minimum 37 , rata-rata 53,56, varians 58,77 dan standar deviasi yaitu 7,32. Dari data hasil posttest tersebut diperoleh bahwa nilai rata-rata kelas eksperimen lebih tinggi dari nilai rata-rata kelas kontrol, selisih nilai ratarata posttest kelas eksperimen dan kelas kontrol adalah 10,57. Hasil ini menunjukkan bahwa kemampuan penalaran matematis siswa yang diajarkan dengan model pembelajaran kooperatif tipe Numbered Head Together (NHT) lebih tinggi daripada kemampuan penalaran matematis siswa yang diajarkan dengan model pembelajaran konvensional.

Membandingkan kemampuan penalaran matematis siswa berdasarkan kelompok perlakuan menggunakan uji t. Sebelum menggunakan uji $\mathrm{t}$, terlebih dahulu dilakukan uji normalitas dan uji homogenitas. Uji normalitas akan dilanjutkan dengan uji homogenitas apabila data populasi berdistribusi normal. Data kemampuan penalaran matematis siswa berdistribusi normal jika sig $\alpha \geq 0,05$. Hasil statistik uji normalitas penelitian ini berdasarkan uji chikuadrat dengan bantuan microsoft office excel dapat dilihat pada Tabel II.

TABEL II

HASIL UJI NORMALITAS

\begin{tabular}{llll}
\hline \multicolumn{1}{c}{ Kelas } & $\chi^{2}{ }_{\text {hitung }}$ & $\chi^{2}$ tabel & Keputusan \\
\hline Eksperimen & 3,895 & 7,815 & Berdisribusi normal \\
Kontrol & 2,744 & 7,815 & Berdisribusi normal \\
\hline
\end{tabular}

Tabel II di atas memperlihatkan perhitungan uji normalitas data posttest kelas eksperimen diperoleh harga $\chi^{2}$ hitung $=$ 3,895 dan harga $\chi_{\text {tabel }}^{2} 7,815$ pada taraf signifikan $\alpha=0,05$ . Karena harga $\chi_{\text {hitung }}^{2}=3,895<$ harga $\chi_{\text {tabel }}^{2}=7,815$ maka $\mathrm{H}_{0}$ diterima dan $\mathrm{H}_{1}$ ditolak yang artinya bahwa data posttets kelas eksperimen berasal dari populasi yang berdistribusi normal. Tabel II di atas juga memperlihatkan perhitungan uji normalitas posttest kelas kontrol diperoleh harga $\chi^{2}{ }_{\text {hitung }}=$ 2,744 dan harga $\chi_{\text {tabel }}^{2}=7,815$ pada taraf signifikan $\alpha=0,05$. Karena harga $\chi_{\text {hitung }}^{2}=2,744<$ harga $\chi_{\text {tabel }}^{2}=7,815$ maka $\mathrm{H}_{0}$ diterima dan $\mathrm{H}_{1}$ ditolak yang artinya bahwa data postest kelas kontrol berasal dari populasi yang berdistribusi normal.

Uji homogenitas dilakukan untuk mengetahui apakah sampel yang diteliti berasal dari populasi yang homogen atau tidak. Dan populasi dikatakan homogen dan populasi dikatakan homogen apabila varians dari kedua sampel tersebut sama. Jika $F_{\text {hitung }} \leq F_{\text {tabel }}$ pada taraf signifikan $\alpha=0,05$. Uji homogenitas data kemampuan penalaran matematis dianalisis menggunakan uji F. Hasil uji homogenitas data dengan uji F dpat dilihat pada Tabel III.

TABEL III

HASIL UJI HOMOGENITAS

\begin{tabular}{cccccr}
\hline Kelas & $\mathbf{N}$ & $F_{\text {hitung }}$ & $F_{\text {tabel }}$ & \multicolumn{2}{c}{ Keterangan } \\
\hline Eksperimen & 32 & & & $\begin{array}{l}\text { Kedua } \\
\text { sama }\end{array}$ & atau \\
Kontrol & 32 & 1,136 & 1,822 & $\begin{array}{l}\text { sams } \\
\text { homogen }\end{array}$ \\
\hline
\end{tabular}

Tabel III memperlihatkan hasil perhitungan ujihomogenitas data Posttest kelas eksperimen dan kelas kontrol diperoleh $F_{\text {hitung }}=1,136<F_{\text {tabel }}=1,822$ maka $\mathrm{H}_{0}$ diterima dan $\mathrm{H}_{1}$ ditolak yang artinya kelompok eksperimen dan kelompok kontrol memiliki varians yang sama atau homogen.

Berdasarkan hasil perhitungan uji normalitas dan uji homogenitas data kemampuan penalaran matematis siswa sebagai uji prasyarat untuk melakukan uji $t$ terpenuhi, maka dilanjutkan dengan uji hipotesis. Uji hipotesis dalam penelitian ini digunakan untuk mengetahui apakah kemampuan penalaran matematis siswa yang diajarkan dengan model pembelajaran kooperatif tipe Numbered Head Together (NHT) lebih baik daripada kemampuan penalaran matematis siswa yang diajarkan dengan pembelajaran langsung. Hasil perhitungan uji-t untuk tes kemampuan penalaran matematis siswa dapat dilihat pada Tabel IV.

TABEL IV

HASIL UJI HIPOTESIS

\begin{tabular}{llcc}
\hline \multicolumn{1}{c}{ Kelas } & $t_{\text {hitung }}$ & $t_{\text {tabel }}$ & Kesimpulan \\
\hline $\begin{array}{l}\text { Eksperimen } \\
\text { Kontrol }\end{array}$ & 6,003 & 1,999 & $\begin{array}{c}\text { Hipotesis } \\
\text { diterima }\end{array}$ \\
\hline
\end{tabular}

Dari hasil uji $t$ diperoleh $t_{\text {hitung }}=6,003$ dan harga , karena $t_{\text {hitung }}>t_{\text {tabel }}$, maka $H_{0}$ ditolak dan $H_{1}$ diterima, artinya kemampuan penalaran matematis siswa yang diajarkan dengan model pembelajaran kooperatif Tipe 
Numbered Head Together (NHT) lebih baik dibandingkan dengan kemampuan penalaran matematis siswa yang diajarkan dengan pembelajaran langsung

Temuan ini memperkuat hasil penelitian yang dilakukan oleh beberapa peneliti terdahulu, diantaranya penelitian yang dilakukan oleh Rahmawati (2017) menunjukkan bahwa model pembelajaran kooperatif tipe Numbered Head Together (NHT) lebih baik dari pada pembelajaran langsung, karena rerata NHT sebesar 61.94 sedangkan untuk hasil rerata pembelajaran langsung sebesar 56.71, yang artinya rerata NHT lebih besar dari rerata konvensional. Selain itu, hasil penelitian yang dilakukan oleh Lince (2016) juga menunjukkan bahwa model pembelajaran kooperatif tipe Numbered Head Together (NHT) dapat meningkatkan kemampuan berpikir kreatif siswa dalam pembelajaran matematika. Selanjutnya, penelitian yang dilakukan Khoirotunnisa (2015) diperoleh kesimpulan bahwa prestasi belajar matematika siswa yang diajarkan dengan model pembelajaran kooperatif tipe Numbered Head Togethet (NHT) lebih baik dari pada prestasi belajar matematika siswa yang diajarkan dengan pembelajaran konvensional, serta penelitian yang dilakukan oleh Sutriningsih et al., (2018) juga menunjukkan bahwa penggunaan model pembelajaran kooperatif tipe Numbered Head Together (NHT) dalam pembelajaran matematika memberikan hasil yang lebih baik dari pada pembelajaran konvensional, karena rerata NHT sebesar 89,80 sedangkan untuk hasil rerata pembelajaran konvensional sebesar 68,72 yang artinya rerata NHT lebih besar dari rerata konvensional.

Adanya perbedaan kemampuan penalaran matematis antara siswa pada kelas eksperimen dan siswa pada kelas kontrol, disebabkan karena tahapanmodel pembelajaran kooperatif tipe Numbered Head Together (NHT) memberikan kesempatan kepada siswa untuk berinteraksi, bertanggung jawab, serta saling bertukar ide untuk menemukan jawaban kelompok yang paling tepat sehingga siswa mengalami perubahan baik dalam hal mengikuti langkah-langkah model pembelajaran model pembelajaran kooperatif tipe Numbered Head Together (NHT) maupun dalam hal kemampuan penalaran matematis.

Setiap siswa terlihat antusias mengikuti setiap tahapan pembelajaran kooperatif tipe Numbered Head Together (NHT). Pada tahap penomoran siswa dibagi kedalam kelompok yang terdiri dari 3-5 orang, setiap siswa dalam setiap kelompok mendapat nomor yang berbeda sehingga semua siswa bertanggung jawab dan berusaha memahami setiap prosedur penyelesaian soal matematika dengan cara bernalar.

Pada tahap berpikir bersama, semua siswa dalam setiap kelompok mendiskusikan jawaban dari soal yang diberikan. Dalam menyelesaikan soal yang diberikan, setiap siswa dalam setiap kelompok saling bertukar ide untuk mengajukan dugaan, menyajikan pernyataan matematis, melakukan manipulasi matematika, menemukan pola atau sifat dari gejala matematis untuk membuat generalisasi, menarik kesimpulan dari suatu pernyataan, memeriksa kesahihan dari suatu argumen, serta memberikan kesimpulan, menyusun bukti, memberikan alasan atau bukti terhadap beberapa solusi dengan benar, sehingga semua siswa dapat mengembangkan kemampuan penalaran matematisnya.

Pada tahap pemberian jawaban, tampak bahwa semua siswa mempersiapkan diri untuk mempresentasikan jawaban kelompoknya di depan kelas. Ketika guru memanggil salah satu nomor tertentu, siswa yang mendapat nomor tersebut wajib mempresentasikan hasil kerja kelompoknya di depan kelas.

Pada kelas kontrol yaitu kelas yang diajarkan dengan menggunakan model pembelajaran konvensional, siswa hanya mendengarkan penjelasan dari guru, ketika diberi kesempatan untuk bertanya, banyak diantaranya yang hanya diam saja. Dari sekian banyak siswa yang ada pada kelas kontrol, hanya beberapa siswa saja yang terlibat aktif dalam proses pembelajaran. Sebagian besar siswa pada kelas kontrol masih kesulitan dalam menemukan langkah-langkah penyelesaian soal yang tepat, sehingga menghambat respon siswa dan membatasi penguasaan siswa terhadap materi yang sedang dibahas.Diakhir perlakuan, masing-masing kelas diberi posttest untuk melihat kemampuan penalaran matematis siswa sebagai akibat dari adanya perlakuan tersebut. Dalam penelitian ini untuk masing-masing kelas peneliti melaksanakan pembelajaran dengan jumlah 5 pertemuan dan ditambah 1 pertemuan untuk posttest.

\section{KESIMPULAN}

Berdasarkan analisis data dan pengujian hipotesis yang telah dilakukan, dapat disimpulkan bahwa penggunaan model pembelajaran kooperatif tipe Numbered Head Together (NHT pada kelas eksperimen memiliki pengaruh terhadap kemampuan penalaran matematis siswa. Rata-rata kemampuan penalaran matematis siswa kelas eksperimen lebih tinggi dibandingkan rata-rata kemampuan penalaran matematis siswa kelas kontrol. Hal ini dapat dilihat dari hasil perhitungan dengan menggunakan uji $\mathrm{t}$ bahwa $t_{\text {hitung }}=$ 6,003 dan $t_{\text {tabel }}=1,999$. Sehingga dengan temuan ini, model pembelajaran kooperatif tipe Numbered Head Together (NHT) dapat dijadikan sebagai salah satu alternatif pendekatan pembelajaran matematika atau ilmu lainnya yang dapat gunakan di dalam kelas.

\section{REFERENSI}

Ainun, N. (2015). Peningkatan Kemampuan Penalaran Matematis Siswa Madrasah Aliyah Melalui Model Pembelajaran Kooperatif Tipe Teams Games Tournament. Jurnal Peluang.

Ali, F. A., Murni, V., \& Jelatu, S. (2018). Analisis Kesulitan Mahasiswa dalam Menyelesaikan Masalah Matematis Bermuatan HOTS Ditinjau dari Kemampuan Koneksi Matematis. Journal of Songke Math, 1(2), 32-46.

Altun, M., \& Memnun, D. S. (2008). Mathematics teacher trainees' skills and opinions on solving non-routine mathematical problems. Journal of Theory and Practice in Education, 4(2), 213-238.

Bardini, C., Pierce, R., Vincent, J., \& King, D. (2014). Undergraduate Mathematics Students' Understanding 
of Concept of Function. IndoMS-JME, 5(2), 85-107.

Depdiknas. (2006). Panduan Penyusunan Kurikulum Tingkat Satuan Pendidikan. Jakarta: BNSP Depdiknas.

Faradillah, A. (2018). Analysis of Mathematical Reasoning Ability of Pre-Service Mathematics Teachers in Solving Algebra Problem Based on Reflective and Impulsive Cognitive Style. Formatif: Jurnal Ilmiah Pendidikan MIPA, 8(2), 119-128. https://doi.org/10.30998/formatif.v8i2.2333

Hendriana, H., \& Sumarmo, U. (2014). Penilaian Pembelajaran Matematika. Bandung: PT Refika Aditama.

Indarti, D., Mardiyana, \& Pramudya, I. (2017). Numbered head together with scientific approach in geometry learning. Journal of Physics: Conference Series, 943(1), 012028. https://doi.org/10.1088/17426596/943/1/012028

Irawan, A., Mardiyana, \& Sari Saputro, D. R. (2017). Experimentation of cooperative learning model Numbered Heads Together (NHT) type by concept maps and Teams Games Tournament (TGT) by concept maps in terms of students logical mathematics intellegences. Journal of Physics: Conference Series, $855(1), \quad 012019 . \quad$ https://doi.org/10.1088/17426596/855/1/012019

Jelatu, S., Sariyasa, S., \& Ardana, I. M. (2018). Effect of GeoGebra-Aided REACT Strategy on Understanding of Geometry Concepts. International Journal of Instruction, 11(4), 325-336. https://doi.org/10.12973/iji.2018.11421a

Khoirotunnisa, A. U. (2015). Eksperimentasi Model Pembelajaran Numbered Head Together ( Nht ) Dengan Gallery of Learning Pada Pokok Bahasan Bangun Ruang Sisi Lengkung Ditinjau Dari Adversity Quotient Siswa Kelas Viii Smp N Se-Kabupaten Bojonegoro Tahun Pelajaran 2013 / 2014. Magistra, (91), 70-78.

Kurniati, K., Prahmana, R. C. I., Makur, A. P., \& Jelatu, S. (2018). Math Comics, Vectors, and the Strategy of Preview, Question, Read, Reflect, Recite, Review (PQ4R). Formatif: Jurnal Ilmiah Pendidikan MIPA, $8(3)$, $159-174$. https://doi.org/10.30998/formatif.v8i3.2716

Kurnila, V. S. (2013). Kontribusi Standar Proses Pada Kurikulum 2013 Guna Meningkatkan Kemampuan Algoritmik Siswa. Jurnal Pendidikan Dan Kebudayaan Missio, 10(1), 53-58.

Kusuma, A. P., \& Maskuroh, M. (2017). The Differences of Mathematics Learning Outcomes between Think Pair Share (TPS) and Number Heads Together (NHT). AlJabar: Jurnal Pendidikan Matematika, 9(10), 19-24.

Leasa, M., \& Corebima, A. D. (2017). The effect of numbered heads together (NHT) cooperative learning model on the cognitive achievement of students with different academic ability. Journal of Physics: Conference Series, 795(11), 012071. https://doi.org/10.1088/17426596/795/1/012071
Lehrer, R., \& Schauble, L. (2000). Developing Model-Based Reasoning in Mathematics and Science. Journal of Applied Developmental Psychology, 21(1), 39-48. https://doi.org/10.1016/S0193-3973(99)00049-0

Lince, R. (2016). Creative Thinking Ability to Increase Student Mathematical of Junior High School by Applying Models Numbered Heads Together. Journal of Education and Practice, 7(6), 206-212. Retrieved from

http://search.ebscohost.com/login.aspx?direct=true\&d $\mathrm{b}=$ eric \&AN=EJ1092494\&site=ehost-live

Mueller, M., Yankelewitz, D., \& Maher, C. (2014). Teachers Promoting Student Mathematical Reasoning. Investigations in Mathematics Learning, 7(2), 1-20. https://doi.org/10.1080/24727466.2014.11790339

Rahmawati, N. K. (2017). Implementasi Teams Games Tournaments dan Number Head Together ditinjau dari Kemampuan Penalaran Matematis. Al-Jabar: Jurnal Pendidikan Matematika, 8(2), 121. https://doi.org/10.24042/ajpm.v8i2.1585

Ratnasari, G. I., \& Abadi, A. M. (2018). Investigating mathematical literacy, mathematical reasoning skill, and self esteem of a public high school. Journal of Physics: Conference Series, 1097(1), 012096. https://doi.org/10.1088/1742-6596/1097/1/012096

Riyanto, B., \& Siroj, R. A. (2011). Meningkatkan Kemampuan Penalaran dan Prestasi Matematika dengan Pendekatan Kondstruktivisme pada Siswa Sekolah Menengah Atas. Jurnal Pendidikan Matematika, 5(2), 111-128.

Sugihatno, A. C. M. S., Budiyono, \& Slamet, I. (2017). Realistic Matematic Approach through Numbered Head Together Learning Model. Journal of Physics: Conference Series, 895(1), 012026. https://doi.org/10.1088/1742-6596/895/1/012026

Sutriningsih, N., Pratiwi, R., \& Utami, B. H. S. (2018). Penerapan Model Pembelajaran Kooperatif Tipe Numbered Head Together (NHT) pada Materi Sistem Persamaan Linear Dua Variabel (SPLDV). JURNAL EDuMath, 4(2), 11. https://doi.org/10.26638/je.717.2064

Unal, H. (2005). The Influence of Curiosity and Spatial Ability on Preservice Middle and Secondary Mathematics Teachers ' Understanding of Geometry.

Wahyuni, A. (2018). Comparison effectiveness of cooperative learning type STAD with cooperative learning type TPS in terms of mathematical method of Junior High School students. Journal of Physics: Conference Series, 1013(1). https://doi.org/10.1088/1742-6596/1013/1/012212

Young, B., Edwards, C., \& Leising, J. (2010). Does a MathEnhanced Curriculum and Instructional Approach Diminish Students' Attainment of Technical Skills? A Year-Long Experimental Study in Agricultural Power and Technology. Journal of Agricultural Education, $50(1)$,

116-126. 